\title{
Role of p16 and p14ARF in radio- and chemo- sensitivity of malignant gliomas
}

\author{
MATTHIAS SIMON ${ }^{1}$, DAVID VOSS ${ }^{1}$, TJOUNG-WON PARK-SIMON ${ }^{2}$, \\ RALPH MAHLBERG ${ }^{1}$ and GERTRAUD KÖSTER ${ }^{1}$ \\ Departments of ${ }^{1}$ Neurosurgery, ${ }^{2}$ Obstetrics and Gynecology, University of Bonn, \\ Sigmund-Freud-Strasse 25, 53105 Bonn, Germany
}

Received March 2, 2006; Accepted March 27, 2006

\begin{abstract}
In addition to cytoreductive surgery, most patients with malignant gliomas also undergo radio- and chemotherapy. An improved understanding of the molecular genetic mechanisms underlying the radio- and chemosensitivity of gliomas may help to identify glioma patients who will benefit from aggressive and, therefore, potentially toxic adjuvant treatment. It may also allow for the development of new therapies aimed at improving the response of these tumors towards chemo- and radiotherapy. The INK4a gene products, p16 and p14ARF, have been suggested as potential regulators of glioma chemo- and radiosensitivity. We have used tetracycline controlled expression of p16 and plasmid-based p14ARF expression to study the chemo- and radiosensitivity of glioma cell lines. Ectopic p16 sensitized U-87MG cells towards treatment with vincristine and possibly also BCNU by approximately 1.5 to 2 -fold, and towards ionizing radiation by a factor of 1.5. p14ARF expression was found to render U-87MG cells 2-fold more radioresistant than controls. These findings support a role for $\mathrm{p} 16$ and p14ARF as modulators of the radio-and chemosensitivity of gliomas. Further studies of the role of cell cycle regulators in glioma chemo- and radio-sensitivity seem warranted. We would like to point out that such candidate genes which may code for potent growth suppressors (like p16) or even toxic gene products can be successfully investigated using the approach detailed in this manuscript.
\end{abstract}

\section{Introduction}

Malignant astrocytomas account for more than $50 \%$ of primary brain tumors. The median survival for patients with glioblastoma multiforme WHO grade IV did not exceed 15

Correspondence to: Dr Matthias Simon, Neurochirurgische Universitätsklinik, Sigmund-Freud-Str. 25, 53105 Bonn, Germany

E-mail: matthias.simon@ukb.uni-bonn.de

Key words: p16, p14ARF, glioma, chemosensitivity, radiosensitivity months in a recent prospective trial (1). The prognosis for patients with anaplastic astrocytomas of WHO grade III is somewhat better with a median survival of 14-36 months (2).

Surgery for glioblastomas and anaplastic astrocytomas can provide a histological diagnosis and reduce the overall tumor cell burden. The prognostic influence of the extent of the resection remains controversial (3). Involved field external beam radiotherapy with a safety margin of $2-3 \mathrm{~cm}$ has been shown to significantly prolong life in patients with malignant gliomas (4). The results of recent studies support the use of chemotherapy for recurrent anaplastic astrocytomas and glioblastomas $(5,6)$. Adjuvant PCV chemotherapy (procarbazine, lomustine/CCNU, vincristine) may confer a survival advantage to patients with anaplastic astrocytomas $(7,8)$. A modest survival benefit but a remarkable increase of midterm survivors was observed in a recently completed prospective randomized trial after radiochemotherapy with temozolomide followed by temozolomide chemotherapy (1).

Chemo- and radiosensitivity of tumors must be determined to some extent by their genetic make-up. Genetic losses of markers from chromosomes $1 \mathrm{p}$ and $19 \mathrm{q}$ may predict chemosensitivity in oligodendroglial tumors (9). Some data suggest that chromosome 1p (and 19q?) losses might also correlate with chemosensitivity in malignant astrocytic and mixed gliomas (10). Deletions of the INK4a/INK4b locus coding for the tumor suppressors and cell cycle regulators p16, p15 and p14ARF have been inversely correlated with the chemosensitivity of malignant gliomas (9). Tumor cells respond to radiation injury by a p53-dependent cell cycle arrest and DNA repair or, alternatively, undergo apoptosis (11). Hence, mutations of cell cycle regulators are attractive candidate lesions influencing the radiosensitivity of the tumor.

Disruption of the INK4a/INK4b locus is seen in more than $30 \%$ of malignant astrocytomas (12). The INK4a gene encodes the tumor suppressor, p16, which arrests cell cycle progression through inhibition of cdk4-mediated pRB phosphorylation. Alternative splicing of the INK4a gene results in the expression of a second protein (p14ARF) with cell cycle inhibitory capacities structurally unrelated to p16. p14ARF promotes the degradation of mdm2 and thus stabilizes p53 protein (13). The structurally and functionally closely related cdk4 inhibitor, p15, is encoded by the INK4b gene separated from the INK4a locus by only $30 \mathrm{~kb}$ (14). p16, p14ARF and their major down-stream targets, $\mathrm{pRB}$ and $\mathrm{p} 53$, play prominent 
roles in cell cycle control, DNA damage detection and repair, and apoptosis, which renders them attractive candidate regulators of radio- and chemosensitivity $(13,15-17)$.

Several groups have, therefore, attempted to delineate systematic p16 and p14ARF effects on the chemo- and radiosensitivity in cell cultures including, to some extent, glioma cell lines. Conflicting data have been reported. In the present study, we used tetracycline-controlled p16 expression and transfection with a p14ARF expression plasmid in glioma cells to investigate a potential role for $\mathrm{p} 16$ and p14ARF in the chemo- and radiosensitivity of gliomas.

\section{Materials and methods}

Cell lines U-87MG-tTA-p16 and U-373MG-tTA-p16. Glioblastoma cell lines U-87MG and U-373MG were purchased from the American Type Culture Collection (ATCC). The construction and characteristics of the cell lines, U-87MGtTA-p16 U87 and U-373MG-tTA-p16, were previously described (18). Both cell lines express no endogenous p16 protein. If grown in cell culture medium containing $2 \times 10^{-3}$ $\mathrm{mg} / \mathrm{ml}$ tetracycline, no p16 protein was detectable by Western blotting. p16 could be detected $8 \mathrm{~h}$ (U-373MG-tTAp16) and $72 \mathrm{~h}$ (U-87MG-tTA-p16) after tetracycline withdrawal. Maximum levels were reached after $24 \mathrm{~h}$ (U373MG-tTA-p16) and $96 \mathrm{~h}$ (U-373MG-tTA-p16), exceeding expression levels observed in HeLa and U-373MG clones still expressing p16 approximately 2-fold (18). Stable p16 expression was observed for more than 12 days in both cell lines. Adding tetracycline to the culture medium resulted in decreasing p16 levels after $12 \mathrm{~h}$ (both cell lines) and no detectable p16 protein after $36 \mathrm{~h}$ (U-373MG-tTA-p16) and $72 \mathrm{~h}$ (U-373MG-tTA-p16). Growing both cell lines at a tetracycline concentration of $5 \times 10^{-6} \mathrm{mg} / \mathrm{ml}$ led to $\mathrm{p} 16$ protein levels comparable to the amount of p16 protein detected in HeLa, Hs683, glioblastoma tissue samples, and in p16 positive U-373MG clones.

Construction and characterization of p14ARF expressing $U$ $87 M G$ clones. A p14ARF expression plasmid based on the expression plasmid, pBabePuro, was used to transfect U-87MG cells with a lipofection protocol as previously described (18). Subclones (U-87MG-pBabePuro-p14ARF) were picked and expanded in cell culture medium containing $8 \mu \mathrm{g} / \mathrm{ml}$ puromycin. Control clones (U-87MG-pBabePuro) were constructed following the same protocols but using the expression vector without an insert. The subclones were tested for p14ARF expression by RT-PCR. The protocols for p14ARF RT-PCR using co-amplification of GAPDH as an internal control for mRNA integrity in order to exclude DNA contamination have been published previously (19).

Chemosensitivity testing. Chemosensitivity testing was performed with vincristine and BCNU. These agents were chosen based on their frequent clinical use, and on their cell cycle dependent vs. independent cytotoxic effects. Vincristine interrupts the assembly of the mitotic spindle in the M phase (20). Hence its cytotoxic effects strongly depend on the cell cycle phase. In contrast, the nitrosoureas, e.g. BCNU/ carmustine and $\mathrm{CCNU} /$ lomustine are cell cycle independent agents (20). Vincristine is administered together with CCNU and procarbazine in the PCV chemotherapy protocol for malignant gliomas $(7,8,20)$. Nitrosourea monotherapy has been used for gliomas, and the PCV protocol as well as many other polychemotherapy protocols include nitrosoureas $(4,20)$. BCNU can also be administered intravenously and, therefore, easily in cell culture. Two other chemotherapeutic agents (procarbazine and temozolomide) commonly used for gliomas $(5,6,20)$ act also cell cycle independent through the alkylation of cellular RNA, DNA and proteins.

Vincristine serum concentrations $>10^{-4} \mathrm{mg} / \mathrm{ml}$ (21) and BCNU concentrations $>10^{-3} \mathrm{mg} / \mathrm{ml}$ (22) have been reported. $\mathrm{BCNU}$ but not vincristine crosses the intact blood brain barrier. However, the blood brain barrier is defective in malignant gliomas. In vitro chemosensitivity testing of astrocytoma biopsies identified LD50s in the range of $10^{-10}$ to $10^{-6} \mathrm{mg} / \mathrm{ml}$ vincristine and $10^{-4}$ to $10^{-3} \mathrm{mg} / \mathrm{ml} \mathrm{CCNU}$ for sensitive tumors (23). Clinically, BCNU and CCNU are used at similar doses. We investigated vincristine/BCNU concentrations ranging from $10^{-8}$ to $10^{-2} \mathrm{mg} / \mathrm{ml}$, and $3 \times 10^{-4}$ to $3 \times 10^{-1} \mathrm{mg} / \mathrm{ml}$. Testing for statistical significance was performed at vincristine concentrations of $10^{-6} \mathrm{mg} / \mathrm{ml}$, and BCNU concentrations of $10^{-3} \mathrm{mg} / \mathrm{dl}$ (Student's t-test).

The protocols for chemosensitivity testing were extensively optimized. Cells were seeded and grown in 96-well titer plates at variable numbers taking into account the growth suppressive effects of p16 and p14ARF, and the respective duration of the cell cycle, in order to ensure that all experiments were performed during the exponential growth phase. The cells (still expressing the transgenes) were allowed to rest after exposure to the chemotherapeutic agents in order to allow for an optimal manifestation of any chemoprotective or chemosensitizing effects. MTS assays were performed to determine the fraction of surviving cells after exposure to the chemotherapeutic agents using a commercially available kit (CellTiter 96Oc AQueous, Promega, Madison, WI, USA) and untreated cells for controls.

Specific protocols were as follows: initial cell numbers (U373MG-tTA-p16: 5000/well, U-87MG-tTA-p16: 1000/well), tetracycline withdrawal after $24 \mathrm{~h}$ (U-87MG-tTA-p16 and U373MG-tTA-p16U373), exposure to cytostatic drugs (U373MG-tTA-p16: 48-96 h, U-87MG-tTA-p16: 96-144 h); MTS assays (U-373MG-tTA-p16: 144 h, U-87MG-tTA-p16: $168 \mathrm{~h}$ ). U-87MG-pBabePuro-p14ARF and U-87MGpBabePuro cells were seeded at 5000 cells/well, allowed to rest for $24 \mathrm{~h}$, exposed to the chemotherapeutic agents for $48 \mathrm{~h}$, and analyzed after $120 \mathrm{~h}$.

Radiosensitivity testing. Radiosensitivity testing protocols were optimized to take into account the growth inhibitory effects of p16 and p14ARF. Cell lines U-87MG-tTA-p16, U373MG-tTA-p16, and U-87MG-pBabePuro-p14ARF/U87MG-pBabePuro cells were seeded in triplicate in standard cell culture dishes at 1000-3000 cells/dish and allowed to rest for $24 \mathrm{~h}$ in the appropriate cell culture medium containing tetracycline as needed. Radiation was delivered by a conventional X-ray unit/tube at $200 \mathrm{kV}, 14 \mathrm{~mA}$ and 2,85 Gy/min. In order to determine clonogenicity after exposure to the various radiation doses, cell colonies were fixed approximately 1 week later on the dishes, stained with hematoxylin, and the 
A
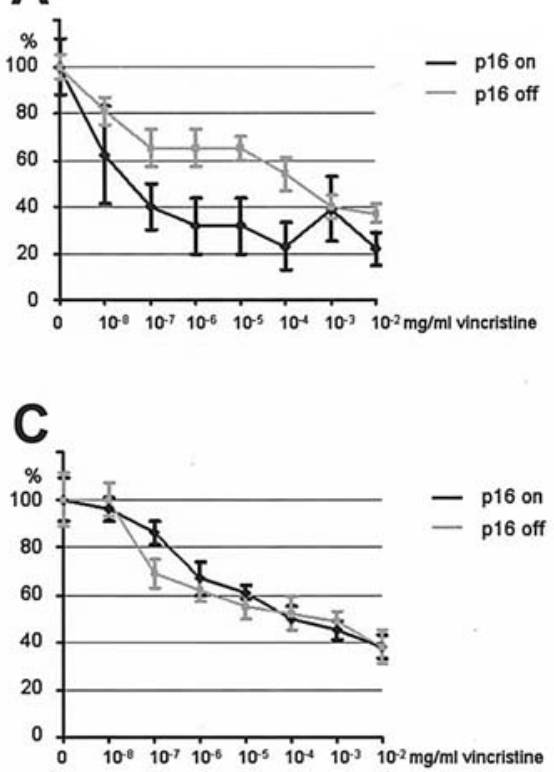

B

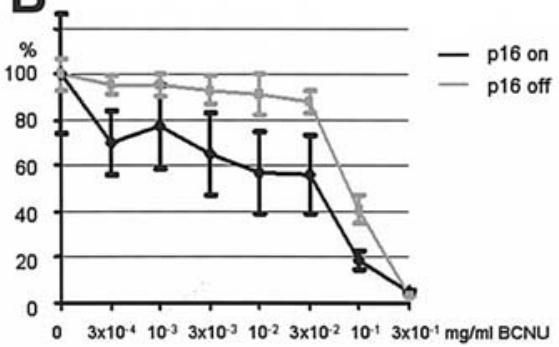

D

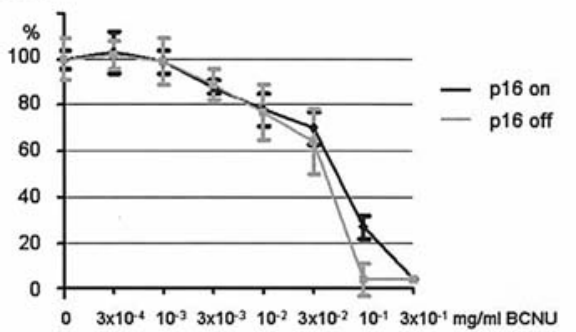

Figure 1. Results of chemosensitivity testing of glioma cell lines U-87MG-tTA-p16 and U-373MG-tTA-p16. Both cell lines conditionally express p16 under the control of a tetracycline-sensitive promoter (p16 on, normal levels of p16 expression; p16 off, no p16 expression, as assessed by immuno-blotting and comparison with cell lines harbouring intact p16 genes). Cells were seeded in multiplicates (6x) and treated with vincristine or BCNU at the indicated concentrations. The fraction of surviving cells was determined using MTS assays. Mean values and standard deviations are shown. (A) Treatment of U87MG-tTA-p16 cells with vincristine. Ectopic p16 significantly sensitized the cells towards the chemotherapeutic agent by approximately 2 -fold (at $10^{-6}$ mg vincristine/ml: $\mathrm{p}<0.001$, Student's t-test). (B) Treatment of U-87MG-tTA-p16 cells with BCNU. A similar chemo-sensitizing effect of p16 is observed, but due to relatively large standard deviations results were only of marginal statistical significance (at $10^{-4} \mathrm{mg} B C N U / \mathrm{ml}: \mathrm{p}<0.05, \mathrm{Student} \mathrm{s}$-test). (C) Treatment of U-373MG-tTA-p16 cells with vincristine. Ectopic p16 has no influence on the sensitivity of the cells towards vincristine. (D) Treatment of U-373MG-tTAp16 cells with BCNU. No chemosensitizing or chemoprotective effects were observed.

colonies were counted. Statistical analysis (Student's t-test) was performed for the radiation dose, resulting in a $>50 \%$ reduction of clonogenicity for both cell lines, compared in the respective experiment.

\section{Results}

Chemo- and radiosensitivity testing of U-87MG-tTA-p16 and $U-373 M G-t T A-p 16$ cells. Tetracycline-controlled p16 expression resulted in a survival disadvantage for U-87MG-tTAp16 cells treated with vincristine, i.e. ectopic expression of p16 increased the chemosensitivity of the cell line (LD50s $3 \times 10^{-8}$ vs. $2 \times 10^{-4}$ vincristine $\mathrm{mg} / \mathrm{dl}$; Fig. $1 \mathrm{~A}$ ). At a vincristine concentration of $10^{-6} \mathrm{mg} / \mathrm{ml}$, an approximate 2-fold increase in the fraction of surviving cells was noted for p16-negative cells $(\mathrm{p}<0.001$, Student's t-test). p16 expression also seemed to increase the chemosensitivity of U-87MG-tTA-p16 cells towards BCNU by a factor of 1.5. However, these latter effects were only of marginal statistical significance (Fig. 1B; at $10^{-4} \mathrm{mg} \mathrm{BCNU/ml:} \mathrm{p}<0.05$, Student's t-test).

p16 expression did not significantly influence the sensitivity of U-373MG-tTA-p16 cells towards vincristine and BCNU. Figs. 1C and D show the results of typical experiments. Of note, U-373MG-tTA-p16 (but also U-87MG-tTA-p16) cells proved rather resistant towards $\mathrm{BCNU}$.

When controlled for antiproliferative effects, expression of the p16 transgene enhanced the radiosensitivity of U-87MGtTA-p16 cells by a factor of 1.5 (Fig. $2 \mathrm{~A} ; 4$ Gy: p $<0.01$, Student's t-test). p16 expression did not significantly influence the radiosensitivity of U-373MG-tTA-p16 cells (Fig. 2B).
Influence of p14ARF on the chemo- and radiosensitivity of U-87MG cells. U-87MG-pBabePuro-p14ARF and U-87MGpBabePuro subclones showed a variable chemosensitivity towards vincristine and $\mathrm{BCNU}$. The LD50s observed ranged from $10^{-7}$ to $10^{-6} \mathrm{mg} / \mathrm{ml}$ vincristine and $10^{-3}$ to $10^{-1} \mathrm{mg} / \mathrm{ml}$ BCNU for the U-87MG-pBabePuro-p14ARF clones. For U87MG-pBabePuro subclones, we observed LD50s in the range of $10^{-6} \mathrm{mg} / \mathrm{ml}$ vincristine and $10^{-2} \mathrm{mg} / \mathrm{ml} \mathrm{BCNU}$. The results were normalized and combined (Fig. $3 \mathrm{~A}$ and $\mathrm{B}$ ). No significant influence of p14ARF on the sensitivity of the cells tested was found towards either vincristine or BCNU.

Radiation doses of $2-3$ Gy resulted in a $>50 \%$ reduction of clonogenicity in all U-87MG-pBabePuro-p14ARF and U87MG-pBabePuro subclones tested. After normalization and combination of the results, a significant radioprotective effect was demonstrated for ectopic p14ARF expression (Fig. 3C). p14ARF expressing subclones proved approximately twice as radioresistant as the p14ARF negative controls (at 3 Gy: $\mathrm{p}<0.001$, Student's t-test).

\section{Discussion}

A better understanding of the genetic basis of radio- and chemosensitivity holds the promise of identifying tumors which will respond to such treatments and thus optimize the overall outcome (24). Patients with chemo- and radiosensitive tumors could be treated more aggressively, while others could be spared ineffective and potentially toxic treatment. The increasing costs of (new) antineoplastic drugs provide further arguments for a more selective approach to chemotherapy (25). 
A

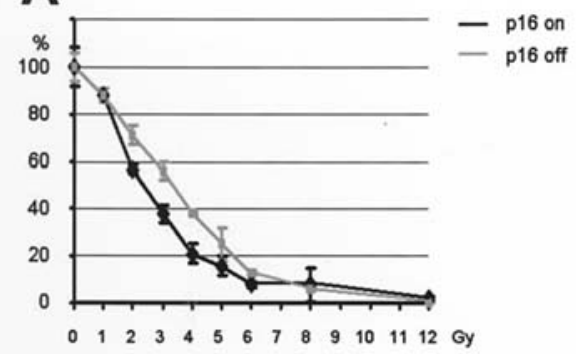

B

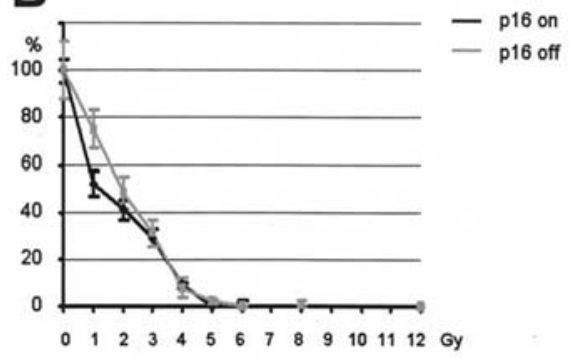

Figure 2. Results of radiosensitivity testing of glioma cell lines U-87MG-tTA-p16 and U-373MG-tTA-p16. Both cell lines conditionally express p16 under the control of a tetracycline-sensitive promoter (p16 on, normal levels of p16 expression; p16 off, no p16 expression, as assessed by immuno-blotting and comparison with cell lines harbouring intact p16 genes). Cells were seeded in triplicates and radiated as indicated. Clonogenicity was determined by counting visible colonies after staining of the cell culture dishes. Mean values and standard deviations are shown. (A) Radiation treat-ment of U-87MG-tTA-p16 cells. Ectopic p16 significantly (x1.5) sensitized the cells towards radiation treatment (at 4 Gy: p<0.01, Student's t-test). (B) Radiation treatment of U-373MG-tTAp16 cells. Ectopic p16 has no influence on the radiosensitivity of the cells.
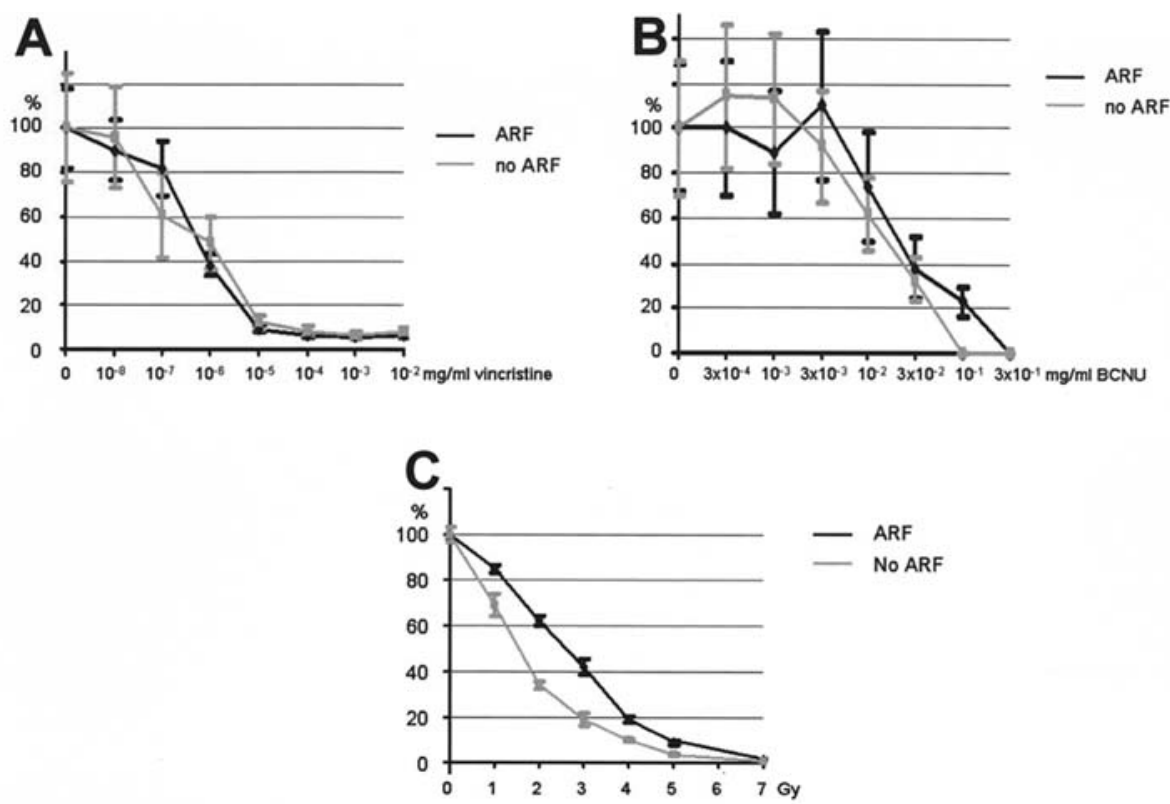

Figure 3. Results of chemo- and radiosensitivity testing of U-87MG glioma cells. After transfection with a p14ARF expression plasmid (pBabePuro-p14ARF) and a control vector (pBabePuro), three p14ARF positive (ARF) and three p14ARF negative subclones (no ARF) were expanded and analysed for their chemo- and radiosensitivity as described in Materials and methods. The results were normalized and combined. Mean values and standard deviations are shown. (A) Vincristine treatment. Ectopic p14ARF did not significantly influence the sensititvity of U-87MG-pBabePuro-p14ARF cells towards vincristine, when compared with p14ARF negative controls (U-87MG-pBabePuro). (B) BCNU treatment. No significant effects were observed. (C) Radiation treatment of U-87MG cells. p14ARF expression rendered cells significantly more radioresistant when compared to controls (at 3 Gy: $p>0.001$, Student's t-test).

Substantial data points to an important role for the tumor suppressors, p16 and p14ARF, in the development of malignant gliomas (12). Their role in cell cycle control renders them attractive candidates for regulators of chemo- and radiosensitivity. In this study, we have analyzed a potential role for the tumor suppressors, p16 and p14ARF, in the chemo- and radiosensitivity of two glioma cell lines.

p16 expression was found to sensitize U-87MG-tTA-p16 cells towards vincristine and possibly also BCNU. However, the results were only of marginal statistical significance. The fractions of surviving cells differed by approximately 2-fold at vincristine concentrations probably achievable in vivo. No chemosensitizing effects were seen for p16 in U-373MGtTA-p16 cells. Ectopic expression of p14ARF in U-87MG cells did not significantly alter the sensitivity of these cells towards vincristine and BCNU. When controlled for its growth inhibitory effects, ectopic p16 expression increased the radiosensitivity of U-87MG-tTA-p16 cells. Again, no effects were seen in U-373MG-tTA-p16 cells. A radio-protective effect was found for p14ARF expression in U-87MG cells.

Glioma cell lines have been previously used to study a potential role for p16 in chemosensitivity $(26,27)$. Plasmidbased and adenoviral p16 overexpression, respectively, were found to protect glioma cells against treatment with ACNU, cisplatin, paclitaxel and topotecan. In support of these findings, a correlation between chemoresistance and p16 expression in 12 glioma cell lines was recently reported (28). Iwadate et al used astrocytoma biopsy samples harboring p16 and p14ARF 
mutations to show a somewhat similar relationship between loss of p16 expression and increased sensitivity towards antimetabolites (29). On the other hand, and in line with our results obtained with U-87MG-tTA-p16 cells treated with vincristin, a p16-mediated increase in chemosensitivity has been demonstrated in several non-glioma cell lines (30-32).

Ectopic expression of p16 has been used by Miyakoshi et al (33) and Hama et al (34) to investigate a potential role for p16 in glioma radiosensitivity. Similar to our findings for U-87MGtTA-p16 cells, these authors report a radiosensitizing effect mediated by $\mathrm{p} 16$. Their findings are supported by studies in other non-glioma cell lines (35-37).

p14ARF had not been widely investigated previously as a potential determinant of chemo- or radiosensitivity. p14ARF expression can increase the resistance of p53 defective HT1080 fibrosarcoma cells to antimetabolites such as methotrexate (38). Gao et al reported an increase in radiosensitivity after plasmid based ectopic expression in lung cancer cell lines (39). In the study by Iwadate et al (29), p14ARF losses correlated with the sensitivity of astrocytoma biopsy samples towards antimetabolites. p14ARF is a negative cell cycle regulator critically depending on p53 function. p53 plays a major role in apoptosis, DNA damage control and, therefore, chemo- and radiosensitivity $(13,15)$. We have, therefore, utilized U-87MG cells in our p14ARF study, which harbor an intact p53 gene. In contrast, the p53 gene in U-373MG cells is mutant and functionally defective (40). This could explain why U-373MG cells proved generally rather chemoresistant and no significant chemo- and radiosensitizing effects were seen following the ectopic expression of p16 in these cells.

Conflicting data regarding the role of p16 in (glioma) chemo- and radiosensitivity may have resulted in part from the use of cells overexpressing p16. p16 overexpression leads to cell cycle arrest (13), which clearly does not reflect clinical reality. Another problem encountered by most investigators is the introduction of collateral genomic alterations during plasmid-based and adenoviral gene transfer. In addition, the minute efficiency of all transfection techniques for plasmids currently used makes selection for successfully transfected cells necessary. This is a particularly important issue when the gene analyzed codes for a growth suppressor or a toxic gene product.

Inducible expression of transgenes may solve these problems. We employed a tetracycline sensitive promoter to express p16 at levels comparable to cells containing intact INK4a genes as evidenced by Western blotting. We acknowledge that the effects of p14ARF expression in U$87 \mathrm{MG}$ cells may have to be studied using the same method, for the reasons outlined above. However, the availability of the p14ARF expression plasmid at the beginning of this study provided a short-cut which allowed for the acquisition of the data detailed above. Tetracycline-controlled p16-expression was also used by Prabhu et al (41) to investigate the role of p16 in chemosensitivity. They demonstrated differential effects for p16 in osteosarcoma cells treated with etoposide and taxol, or epirubicine. Stone et al found that IPTG controlled ectopic p16 expression increased the resistance of melanoma cells towards vinblastine, methotrexate, and cisplatin (42).

In summary, the results of this investigation support a role for the INK4a gene products, p16 and p14ARF, in glioma chemo- and radiosensitivity. However, the effects observed in this study were comparatively small, and restricted to one of two cell lines. This may limit the clinical relevance of these data. Nevertheless, the apparent role of cycle regulators in the radio- and chemosensitivity of malignant gliomas warrants further study. Examining the influence of specific genes and their mutations on radio- and chemosensitivity in the controlled environment of a cell culture will form an important part of such research. Only in vitro studies will allow for the development of new therapeutic strategies; e.g. modulation of chemoor radiosensitivity by gene transfer (43). Investigating gene products with strong antiproliferative effects in cell culture poses specific challenges. However, these problems may be overcome by following the approach outlined in this manuscript (i.e. using tetracycline controlled expression).

\section{Acknowledgements}

We would like to thank Dr O Labudova, Department of Experimental Radiology and Radiation Biology for help with the radiation experiments. Professor J Schramm, Department of Neurosurgery, University of Bonn, and Dr Christian Simon, Department of Otorhinolaryngology, University of Heidelberg, provided helpful comments. We are grateful to R Mahlberg for expert technical help. This study was funded in part by grants from the Deutsche Forschungsgemeinschaft (Si 552-1, Si 552-2) and the University of Bonn (Bonfor 112/06) to M.S. Part of this work forms the doctoral thesis of DV.

\section{References}

1. Stupp R, Mason WP, van den Bent MJ, Weller M, Fisher B, Taphoorn MJ, Belanger K, Brandes AA, Marosi C, Bogdahn U, Curschmann J, Janzer RC, Ludwin SK, Gorlia T, Allgeier A, Lacombe D, Cairncross JG, Eisenhauer E and Mirimanoff RO; European Organisation for Research and Treatment of Cancer Brain Tumor and Radiotherapy Groups and National Cancer Institute of Canada Clinical Trials Group: Radiotherapy plus concomitant and adjuvant temozolomide for glioblastoma. $\mathrm{N}$ Engl J Med 352: 987-996, 2005.

2. Kristof RA, Neuloh G, Hans V, Deckert M, Urbach H, Schlegel U, Simon M and Schramm J: Combined surgery, radiation, and PCV chemotherapy for astrocytomas compared to oligodendrogliomas and oligoastrocytomas WHO grade III. J Neurooncol 59: 231-237, 2002 .

3. Lacroix M, Abi-Said D, Fourney DR, Gokaslan ZL, Shi W, DeMonte F, Lang FF, McCutcheon IE, Hassenbusch SJ, Holland E, Hess K, Michael C, Miller D and Sawaya R: A multivariate analysis of 416 patients with glioblastoma multiforme: prognosis, extent of resection, and survival. J Neurosurg 95: 190-198, 2001.

4. Walker MD, Green SB, Byar DP, Alexander E Jr, Batzdorf U, Brooks WH, Hunt WE, MacCarty CS, Mahaley MS Jr, Mealey J Jr, Owens G, Ransohoff J II, Robertson JT, Shapiro WR, Smith KR Jr, Wilson CB and Strike TA: Randomized comparisons of radiotherapy and nitrosoureas for the treatment of malignant glioma after surgery. N Engl J Med 303: 1323-1329, 1980.

5. Yung WK, Prados MD, Yaya-Tur R, Rosenfeld SS, Brada M, Friedman HS, Albright R, Olson J, Chang SM, O'Neill AM, Friedman AH, Bruner J, Yue N, Dugan M, Zaknoen S and Levin VA: Multicenter phase II trial of temozolomide in patients with anaplastic astrocytoma or anaplastic oligoastrocytoma at first relapse. Temodal Brain Tumor Group. J Clin Oncol 17: 2762-2771, 1999. Erratum in: J Clin Oncol 17: 3693, 1999.

6. Yung WK, Albright RE, Olson J, Fredericks R, Fink K, Prados MD, Brada M, Spence A, Hohl RJ, Shapiro W, Glantz M, Greenberg H, Selker RG, Vick NA, Rampling R, Friedman H, Phillips P, Bruner J, Yue N, Osoba D, Zaknoen S and Levin VA: A phase II study of temozolomide vs. procarbazine in patients with glioblastoma multiforme at first relapse. Br J Cancer 83: 588-593, 2000. 
7. Levin VA, Silver P, Hannigan J, Wara WM, Gutin PH, Davis RL and Wilson CB: Superiority of post-radiotherapy adjuvant chemotherapy with CCNU, procarbazine, and vincristine (PCV) over BCNU for anaplastic gliomas: NCOG 6G61 final report. Int J Radiat Oncol Biol Phys 18: 321-324, 1990.

8. Medical Research Council Brain Tumor Working Party: Randomized trial of procarbazine, lomustine, and vincristine in the adjuvant treatment of high-grade astrocytoma: a Medical Research Council trial. J Clin Oncol 19: 509-518, 2001.

9. Cairncross JG, Ueki K, Zlatescu MC, Lisle DK, Finkelstein DM, Hammond RR, Silver JS, Stark PC, Macdonald DR, Ino Y, Ramsay DA and Louis DN: Specific genetic predictors of chemotherapeutic response and survival in patients with anaplastic oligodendrogliomas. J Natl Cancer Inst 90: 1473-1479, 1998.

10. Ino Y, Zlatescu MC, Sasaki H, Macdonald DR, StemmerRachamimov AO, Jhung S, Ramsay DA, von Deimling A, Louis DN and Cairncross JG: Long survival and therapeutic responses in patients with histologically disparate high-grade gliomas demonstrating chromosome 1p loss. J Neurosurg 92: 983-990, 2000.

11. Pawlik TM and Keyomarsi K: Role of cell cycle in mediating sensitivity to radiotherapy. Int J Radiat Oncol Biol Phys 59: 928-942, 2004.

12. Ohgaki $\mathrm{H}$ and Kleihues P: Population-based studies on incidence, survival rates, and genetic alterations in astrocytic and oligodendroglial gliomas. J Neuropathol Exp Neurol 64: 479-489, 2005

13. Lowe SW and Sherr CJ: Tumor suppression by Ink4a-Arf: progress and puzzles. Curr Opin Genet Dev 13: 77-83, 2003.

14. Kamb A, Gruis NA, Weaver-Feldhaus J, Liu Q, Harshman K, Tavtigian SV, Stockert E, Day RS III, Johnson BE and Skolnick MH: A cell cycle regulator potentially involved in genesis of many tumor types. Science 264: 436-440, 1994.

15. Harris SL and Levine AJ: The p53 pathway: positive and negative feedback loops. Oncogene 24: 2899-2908, 2005.

16. Liu H, Dibling B, Spike B, Dirlam A and Macleod K: New roles for the RB tumor suppressor protein. Curr Opin Genet Dev 14: 55-64, 2004.

17. Shapiro GI, Edwards CD, Ewen ME and Rollins BJ: p16INK4A participates in a G1 arrest checkpoint in response to DNA damage. Mol Cell Biol 18: 378-387, 1998.

18. Simon M, Koster G, Menon AG and Schramm J: Functional evidence for a role of combined CDKN2A (p16-p14(ARF)/ CDKN2B (p15) gene inactivation in malignant gliomas. Acta Neuropathol 98: 444-452, 1999.

19. Simon M, Koster G, Ludwig M, Mahlberg R, Rho S, Watzka M and Schramm J: Alternative splicing of the p15 cdk inhibitor in glioblastoma multiforme. Acta Neuropathol 102: 167-174, 2001.

20. Rao RD and Buckner JC: Chemotherapy for central nervous system tumors. In: Cancer of the nervous system. Black PM and Loeffler JS (eds). 2nd edition. Lippincott Williams \& Wilkins, Philadelphia, USA, pp193-208, 2005.

21. Owellen RJ, Root MA and Hains FO: Pharmacokinetics of vindesine and vincristine in humans. Cancer Res 37: 2603-2607, 1977.

22. Levin VA, Hoffman W and Weinkam RJ: Pharmacokinetics of BCNU in man: a preliminary study of 20 patients. Cancer Treat Rep 62: 1305-1312, 1978.

23. Morgan D, Freshney RI, Darling JL, Thomas DG and Celik F: Assay of anticancer drugs in tissue culture: cell cultures of biopsies from human astrocytoma. Br J Cancer 47: 205-214, 1983.

24. Hegi ME, Diserens AC, Gorlia T, Hamou MF, de Tribolet N, Weller M, Kros JM, Hainfellner JA, Mason W, Mariani L, Bromberg JE, Hau P, Mirimanoff RO, Cairncross JG, Janzer RC and Stupp R: MGMT gene silencing and benefit from temozolomide in glioblastoma. N Engl J Med 352: 997-1003, 2005.

25. Martikainen JA, Kivioja A, Hallinen T and Vihinen P: Economic evaluation of temozolomide in the treatment of recurrent glioblastoma multiforme. Pharmacoeconomics 23: 803-815, 2005.
26. Fueyo J, Gomez-Manzano C, Puduvalli VK, Martin-Duque P, Perez-Soler R, Levin VA, Yung WK and Kyritsis AP: Adenovirus-mediated p16 transfer to glioma cells induces G1 arrest and protects from paclitaxel and topotecan: implications for therapy. Int J Oncol 12: 665-669, 1998.

27. Hama S, Heike Y, Naruse I, Takahashi M, Yoshioka H, Arita K, Kurisu K, Goldman CK, Curiel DT and Saijo N: Adenovirusmediated p16 gene transfer prevents drug-induced cell death through G1 arrest in human glioma cells. Int J Cancer 77: 47-54, 1998.

28. Weller M, Rieger J, Grimmel C, Van Meir EG, De Tribolet N, Krajewski S, Reed JC, von Deimling A and Dichgans J: Predicting chemoresistance in human malignant glioma cells: the role of molecular genetic analyses. Int J Cancer 79: 640-644, 1998.

29. Iwadate Y, Mochizuki S, Fujimoto S, Namba H, Sakiyama S, Tagawa $\mathrm{M}$ and Yamaura A: Alteration of cdkn2/p16 in human astrocytic tumors is related with increased susceptibility to antimetabolite anticancer agents. Int J Oncol 17: 501-505, 2000.

30. Chow LS, Wang X, Kwong DL, Sham JS, Tsao SW and Nicholls JM: Effect of p16INK4a on chemosensitivity in nasopharyngeal carcinoma cells. Int J Oncol 17: 135-140, 2000.

31. Fukuoka K, Nishio K, Fukumoto H, Arioka H, Kurokawa H, Ishida T, Iwamoto Y, Tomonari A, Suzuki T, Usuda J, Narita N and Saijo N: Ectopic p16(ink4) expression enhances CPT-11induced apoptosis through increased delay in S-phase progression in human non-small-cell-lung-cancer cells. Int J Cancer 86: 197-203, 2000.

32. Jeong YW, Kim KS, Oh JY, Park JC, Baek WK, Suh SI, Suh MH, Lee JC and Cho JW: Exogenous wild-type p16INK4A gene induces delayed cell proliferation and promotes chemo-sensitivity through decreased pRB and increased E2F-1 expressions. Int J Mol Med 12: 61-65, 2003.

33. Miyakoshi J, Kitagawa K, Yamagishi N, Ohtsu S, Day RS III and Takebe $\mathrm{H}$ : Increased radiosensitivity of p16 gene-deleted human glioma cells after transfection with wild-type p16 gene. Jpn J Cancer Res 88: 34-38, 1997.

34. Hama S, Matsuura S, Tauchi H, Yamasaki F, Kajiwara Y, Arita K, Yoshioka H, Heike Y, Mandai K and Kurisu K: p16 Gene transfer increases cell killing with abnormal nucleation after ionising radiation in glioma cells. Br J Cancer 89: 1802-1811, 2003.

35. Fu XY, Zhang SW, Ran RQ, Shen ZH, Gu JX and Cao SL: Restoration of the p16 gene is related to increased radiosensitivity of p16-deficient lung adenocarcinoma cell lines. J Cancer Res Clin Oncol 124: 621-626, 1998.

36. Kawabe S, Roth JA, Wilson DR and Meyn RE: Adenovirusmediated p16INK4a gene expression radiosensitizes non-small cell lung cancer cells in a p53-dependent manner. Oncogene 19: 5359-5366, 2000 .

37. Matsumura $Y$, Yamagishi N, Miyakoshi J, Imamura S and Takebe H: Increase in radiation sensitivity of human malignant melanoma cells by expression of wild-type p16 gene. Cancer Lett 115: 91-96, 1997.

38. Magro PG, Russo AJ, Li WW, Banerjee D and Bertino JR: p14ARF expression increases dihydrofolate reductase degradation and paradoxically results in resistance to folate antagonists in cells with nonfunctional p53. Cancer Res 64: 4338-4345, 2004

39. Gao N, Hu YD, Cao XY, Zhou J and Cao SL: The exogenous wild-type p14ARF gene induces growth arrest and promotes radiosensitivity in human lung cancer cell lines. J Cancer Res Clin Oncol 127: 359-367, 2001.

40. Van Meir EG, Kikuchi T, Tada M, Li H, Diserens AC, Wojcik BE, Huang HJ, Friedmann T, de Tribolet $\mathrm{N}$ and Cavenee WK: Analysis of the p53 gene and its expression in human glioblastoma cells. Cancer Res 54: 649-652, 1994.

41. Prabhu NS, Somasundaram K, Tian H, Enders GH, Satyamoorthy K, Herlyn M and El-Deiry WS: The administration schedule of cyclin-dependent kinase inhibitor gene therapy and etoposide chemotherapy is a major determinant of cytotoxicity. Int J Oncol 15: 209-216, 1999.

42. Stone S, Dayananth P and Kamb A: Reversible, p16-mediated cell cycle arrest as protection from chemotherapy. Cancer Res 56: 3199-3202, 1996.

43. Gottesman MM: Cancer gene therapy: an awkward adolescence. Cancer Gene Ther 10: 501-508, 2003. 